\title{
Lower Jurassic (Pliensbachian) ammonites from Bornholm, Baltic Sea, Denmark
}

\author{
Desmond T. Donovan and Finn Surlyk
}

\begin{abstract}
The Jurassic succession of the island of Bornholm in the Baltic Sea includes the Hettangian lowermost Pliensbachian Rønne Formation, the Lower Pliensbachian Hasle Formation, the Upper Pliensbachian - (?)Lower Aalenian Sorthat Formation and the (?)Upper Aalenian - Bathonian Bagå Formation. Ammonites are only known from the Hasle Formation, and all available ammonite specimens from this formation are described and figured. Material reported by previous authors has been re-examined, together with previously undescribed specimens. Nine genera and eleven species are recognised. The ammonites show that the rocks from which they were collected fall into the Lower Pliensbachian (Carixian) Substage. The lowermost subzone proved in the Hasle Formation is the basal Taylori Subzone of the Jamesoni Zone of the Northwest European Subboreal standard zonation, which marks a marine transgression over underlying marginal marine beds without ammonites belonging to the Rønne Formation. All subzones of the Jamesoni Zone are proved together with the Valdani Subzone of the Ibex Zone. The Upper Pliensbachian (Domerian) Substage, previously reported, is now thought to be unproved by ammonite evidence. The underlying and overlying Rønne and Sorthat Formations are dated by dinoflagellate cysts and terrestrial palynomorphs, and the ammonite occurrences provide important control points for palynostratigraphic dating of the succession.
\end{abstract}

Keywords: Bornholm, Baltic Sea, Lower Jurassic, ammonite fauna

D.T.D., Research School of Geological \& Geophysical Sciences, Birkbeck College and University College London, Gower Street, London WC1E 6BT, UK. E-mail: ucfbo3d@ucl.ac.uk

F.S., Geological Institute, University of Copenhagen, Geocenter Copenhagen, Øster Voldgade 10, DK-1350 Copenhagen K, Denmark.

Ammonites seem to have been first reported from Bornholm by Malling \& Grönwall in 1909. They described a fauna including an ammonite which they correctly recognised as Aegoceras centaurus (d'Orbigny), now placed in Beaniceras, from the locality of Stampen, south-east of Rønne (Fig. 1). This established the presence of rocks dated to the Pliensbachian Stage of the Lower Jurassic marking a different zonal horizon from other ammonites reported from Bornholm, and the locality has not been redescribed.

Malling (1914, p. 269) mentioned three species of ammonites but named only one of them, as Aegoceras pettos, i.e. Coeloceras pettos (Quenstedt). This may be the form recorded below as Coeloceras grenouillouxi (d'Orbigny). Malling (1920) listed six species of ammonites without description or illustration.

The chief contribution to ammonite palaeontology was made by Höhne (1933) who studied the clay pits at Rønne where strata belonging to the Hasle Formation were exposed and collected ammonites in place and from the excavated material. He described and figured four species from which he concluded that the Jamesoni, Ibex and Spinatum Zones were present. This dating is revised below. However, Höhne was principally concerned with the structure and petrography of the coal-bearing sediments and his palaeontological work seems to have been a sideline. 


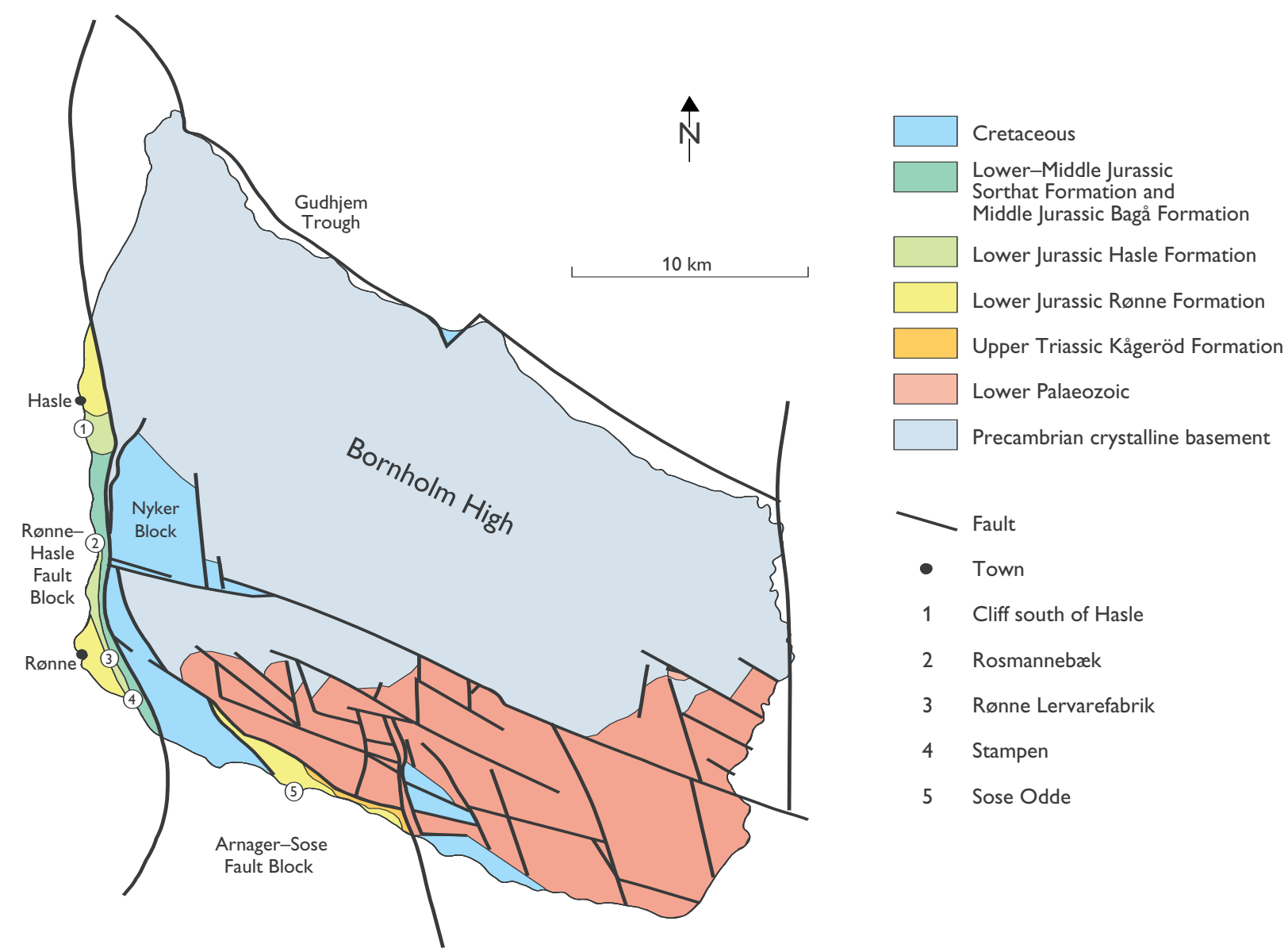

Fig. 1. Geological sketch map of the island of Bornholm in the Baltic Sea showing the position of localities mentioned in the text (modified from Gry 1969 and Gravesen et al. 1982).

No reports on ammonites have appeared in the literature since 1933. The collection examined here belongs to the Geological Museum, University of Copenhagen, and includes a larger number of species than had been previously recognised, eleven species being described below. None of these are new, and although Malling \& Grönwall (1909) and Höhne (1933) both described new varieties, these are now thought to lie within the range of variation of well-known species from elsewhere.

\section{Stratigraphy}

The Jurassic of the island of Bornholm in the Baltic Sea consists of a thickly developed Hettangian-Bathonian succession, whereas Upper Jurassic deposits are absent. Four formations and a number of members are recognized (Gravesen et al. 1982; Koppelhus \& Nielsen 1994; Michelsen et al. 2003, this volume). The Hettangian lowermost Pliensbachian Rønne Formation rests on Triassic redbeds of the Kågeröd Formation and onlaps Lower Palaeozoic sediments or deeply eroded crystalline basement. The Rønne Formation is subdivided into the lacustrine Munkerup Member of Early Hettangian age, the Upper Hettangian - lowermost Pliensbachian paralic Sose Bugt Member and the partly correlative Upper Sinemurian tidally-influenced Galgeløkke Member. The formation is overlain by shoreface sandstones and subordinate clay beds of the Lower Pliensbachian Hasle Formation.

The age of the uppermost part of the Rønne Formation is somewhat uncertain. A few dinoflagellate cysts belonging to Nannoceratopsis senex and Mendicodinium reticulatum with known ranges from the Lower Pliensbachian to the Middle Bajocian were reported from the top of the formation by Surlyk et al. (1995). The oldest ammonites from the overlying Hasle Formation belong to the basal Pliensbachian Jamesoni Zone (Taylori Subzone), and it was tentatively suggested that the dinocysts may have an earlier appearance than previously documented (Surlyk et al. 1995). Two specimens of the ammonite Platypleuroceras brevispina described here from the Sose Odde locality were probably collected in a clay ironstone bed at the top of the Sose Bugt Member (23.1-23.4 m in Surlyk et al. 1995, fig 4). They indicate the Brevispina Subzone of the Jamesoni Zone. The base of the Hasle Formation may thus be diachronous younging from the Taylori Subzone on 
the Rønne-Hasle Block to the Brevispina Subzone on the Arnager-Sose Block.

The Jurassic succession is capped by the paralic, lacustrine and fluvial Upper Pliensbachian - Toarcian (?Lower Aalenian) Sorthat Formation which is overlain by the Bagå Formation of (?Late Aalenian) Bajocian- Bathonian age. The ammonites described in this paper are all from the heterolithic lower parts of the Hasle Formation.

The Hasle Formation is 80-140 m thick and is exposed along the west coast of Bornholm between the towns of Rønne and Hasle. A small outcrop occurs west of Sose Odde on the south coast (Fig. 1). The formation was deposited during an overall rise in relative sea level following deposition of the paralic Rønne Formation (Gravesen et al. 1982; Surlyk \& Noe-Nygaard 1986; Koppelhus \& Nielsen 1994; Surlyk et al. 1995; Michelsen et al. 2003, this volume). The formation consists mainly of brown weathering hummocky cross-stratified finegrained sandstones. Chamositic-oolitic levels and layers of pebbles and pebble-rich zones occur throughout. Intercalated clay beds are common in the Rønne area, where a succession belonging to the formation was formerly exposed at the locality of Rønne Lervarefabrik (Fig. 2). In the literature and in collections, the locality is known as 'Rönne-Lervarefabrik' (Höhne 1933), 'Rønne Lervarefabriks ny Grav' (Malling 1914), 'Rønne Lervarefabrik' (Gry 1969), 'Grube Rønne-Lervareværk', and 'Ny $\varnothing$ stre Lergrav, Rønne'. All ammonites found in the clay pits at Rønne appear to come from this locality which is here called Rønne Lervarefabrik. Höhne (1933) also described a locality which he called 'Rönne Teglverk, Neue Grube', but this is a different locality which exposed slightly younger coal-bearing deposits of the Sorthat Formation. In the section of this paper on systematic palaeontology the ammonite-bearing locality is given as Rønne Lervarefabrik, in each case followed by the locality names written on the original dockets in brackets.

The first thorough description of a marine fauna from the Jurassic of Bornholm was provided by Lundgren (1879) who referred it to the Middle Lias. His material mainly came from loose blocks and the fauna was revised by Moberg (1888) in a study of a contemporaneous fauna found in situ in south-east Skåne, southern Sweden.

A rich marine invertebrate fauna was found in 1906 at the mouth of the Stampea stream on the south coast of Bornholm and was described by Malling \& Grönwall (1909). The fauna includes 56 species and shows great resemblance to the Pliensbachian of north-west Germany. It was referred to the Lower Pliensbachian Centaurus Zone on the basis of the presence of the ammonite Aegoceras centaurus d'Orbigny var. bornbolmiensis Malling \& Grönwall.

Malling (1911) listed a marine fauna with 38 species of bivalves, scaphopods, gastropods, belemnites, ammonites, Hybodus and plesiosaur teeth and rib bones from the low cliffs south of Hasle harbour described by Gravesen et al. (1982), Surlyk \& Noe-Nygaard (1986) and Larsen \& Friis (1991). The ammonite was identified as Arietites falcaries (Quenstedt), i.e. Arnioceras in modern nomenclature (Schlegelmilch 1976, plate 20, fig. 7). Malling took this to indicate the Bucklandi Zone (i.e. Early Sinemurian), which would be correct if the identification was correct. However, this is in contradiction to all the other evidence which indicates a Hettangian - earliest Pliensbachian age for the Rønne Formation and an Early Pliensbachian age for the base of the Hasle Formation. It is likely that the ammonite, which we have not seen, was misidentified. It is possible that this ammonite was a Paltechioceras, as this genus ranges up to the top of the Sinemurian Stage. If so, it would indicate a slightly lower zonal horizon than the lowest inferred in the present paper. Malling (1914) noted the presence of the ammonite Aegoceras, closely related to $A$. maugenestii, from a locality at Rosmannebæk which is only exposed at extreme low water. He also described Aegoceras pettos of the Jamesoni and Centaurus Zones which occurred together with two other ammonite species and about 30 other invertebrate species from exposures of the Hasle Formation at Rønne Lervarefabrik. The ammonites Aegoceras armatum Sowerby var. nodofissus Quenstedt, A. caprarius Quenstedt, A. maugenesti d'Orbigny, Coeloceras pettos Quenstedt, Phylloceras loscombii Sowerby and Oxynoticeras oppelii Schloenbach were listed from the formation by Malling (1920).

\section{Affinities of the ammonite fauna}

All the genera and species now recorded from Bornholm are also found in Germany and England, and most of them have been recorded from north Germany (Hoffmann 1982). One or two species which were not listed by Hoffmann (1982; e.g. Coeloceras grenouillouxi) are closely related to ones that are recorded from north Germany (e.g. C. pettos). The fauna is therefore typical of the Boreal Province. The only point worthy of remark is the absence of the genus Polymorphites which is usually common in Boreal Jamesoni Zone faunas, but in view of the small number of ammonites examined its absence may not be significant. The ammonites show that the rocks from which they were 

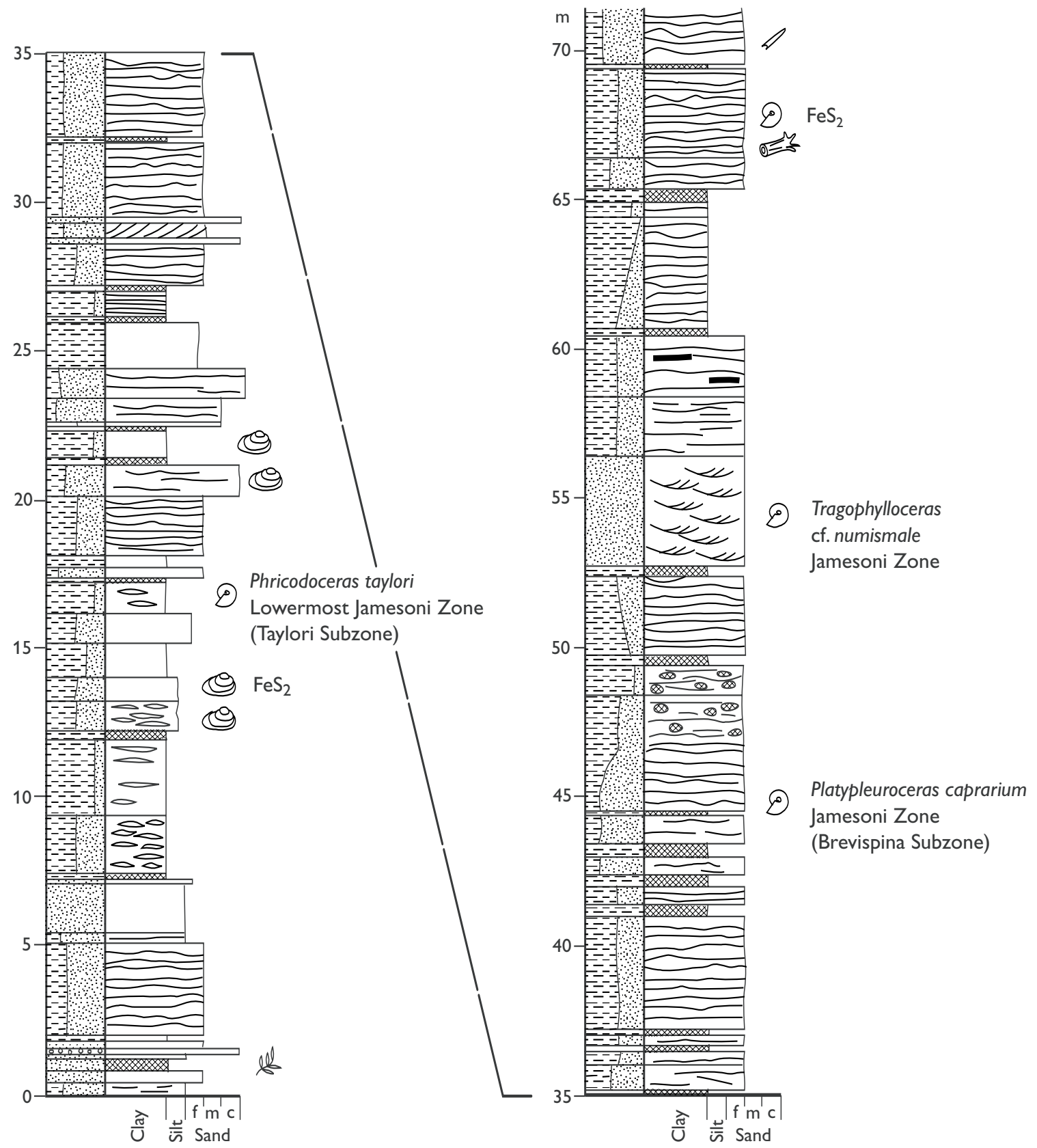

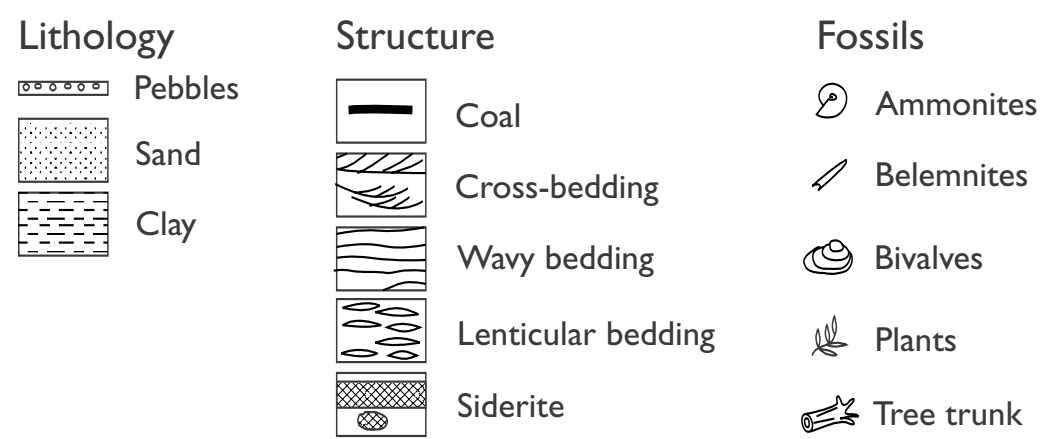

Fig. 2. Lithological section of Rønne Lervarefabrik (Ny Østre Lergrav, Rønne) drawn on the basis of the written description of the stratigraphic succession in Höhne (1933). 
collected fall into the Lower Pliensbachian (Carixian) Substage. The lowermost subzone proved in the Hasle Formation is the basal Taylori Subzone of the Jamesoni Zone of the NW European Subboreal standard zonation (Page 2003, this volume), which marks a marine transgression over underlying marginal marine beds without ammonites belonging to the Rønne Formation. All subzones of the Jamesoni Zone are proved, together with the Valdani Subzone of the Ibex Zone (Fig. 3).

\section{Material}

A total of about 35 specimens representing nine genera and eleven species are described from the Hasle Formation. They include Tragophylloceras numismale (Quenstedt), Tragophylloceras sp., Radstockiceras hechingense Schlatter, Paramicroderoceras fila (Quenstedt), Paramicroderoceras? sp. indet., Coeloceras grenouillouxi (d'Orbigny), Apoderoceras aculeatum (Simpson), Phricodoceras taylori (J. de C. Sowerby), Platypleuroceras brevispina (J. de C. Sowerby), Platypleuroceras submuticum (Oppel), Platypleuroceras caprarium (Quenstedt), Platypleuroceras spp. indet., Uptonia lata (Quenstedt), Uptonia sp. indet., ?Acanthopleuroceras sp. indet., Beaniceras centaurus (d'Orbigny), and Ammonites gen. et sp. indet. All specimens are from the collection of the Geological Museum, University of Copenhagen, and no new material has been added as the clay pits were abandoned many years ago. The material is housed in the Geological Museum, University of Copenhagen (MGUH 25595-25627).

\section{Systematic palaeontology}

Full synonymies for some species would be very long; references are only given here to citations relevant to the discussion and to occurrences on Bornholm.

\section{Suborder Phylloceratina Arkell 1950 Family Juraphyllitidae Arkell 1950}

\section{Genus Tragophylloceras Hyatt 1900}

\section{Tragophylloceras numismale (Quenstedt 1845)}

Plate 1, figs 1-6

1845 Ammonites heterophyllus numismalis Quenstedt, p. 100, plate 6, figs 4a, b, 5a, b, non figs 3a, b, 5c.

\begin{tabular}{|c|c|c|c|}
\hline \multirow{2}{*}{ Stage } & \multirow{2}{*}{ Zone } & \multirow{2}{*}{ Subzone } & $\begin{array}{c}\text { Northwest } \\
\text { European Province }\end{array}$ \\
\hline & & & $\begin{array}{c}\text { Zonule } \\
\text { (NW European s.s.) }\end{array}$ \\
\hline \multirow{26}{*}{ 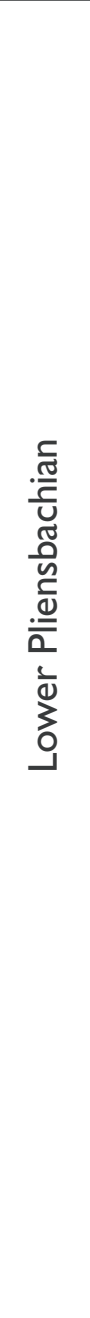 } & \multirow{7}{*}{ Davoei } & \multirow{2}{*}{ Figulinum } & Figulinum \\
\hline & & & Angulatum \\
\hline & & \multirow{3}{*}{ Capricornus } & Crescens/Samontaensis \\
\hline & & & Capricornus \\
\hline & & & Lataecosta \\
\hline & & \multirow{2}{*}{ Maculatum } & Maculatum \\
\hline & & & Sparsicosta \\
\hline & \multirow{11}{*}{ Ibex } & \multirow{3}{*}{ Luridum } & Luridum \\
\hline & & & Crassum \\
\hline & & & Rotundum \\
\hline & & \multirow{7}{*}{ Valdani } & Alisiense \\
\hline & & & Centaurus \\
\hline & & & Venarense \\
\hline & & & Actaeon \\
\hline & & & Valdani \\
\hline & & & Maugenesti \\
\hline & & & Arietiforme \\
\hline & & Masseanum & Masseanum \\
\hline & \multirow{8}{*}{ Jamesoni } & \multirow{2}{*}{ Jamesoni } & Pettos \\
\hline & & & Jamesoni \\
\hline & & \multirow{2}{*}{ Brevispina } & Tenuilobos/Submuticum \\
\hline & & & Brevispina/Brevispinoides \\
\hline & & \multirow{2}{*}{ Polymorphus } & Polymorphus \\
\hline & & & Biruga \\
\hline & & \multirow{2}{*}{ Taylori } & Taylori \\
\hline & & & Nodogigas \\
\hline
\end{tabular}

Fig. 3. Pliensbachian zonal and subzonal subdivision (modified from Page 2003, this volume). On the basis of the ammonite evidence, all four of the subzones of the Jamesoni Zone and the Valdani Subzone of the Ibex Zone (shaded subzones) are represented on Bornholm.

1885 Ammonites heterophyllus numismalis Quenstedt, p. 291, plate 37, figs 8-11, 21.

?1920 Phylloceras Loscombii Sowerby - Malling, p. 55.

1933 Phylloceras heterophyllum numismale Quenstedt - Höhne, p. 56, plate 14, figs 2, 3.

1964 Tragophylloceras numismale (Quenstedt) Howarth \& Donovan, p. 295, plate 48, fig. 5.

1976 Tragophylloceras numismale (Pompeckj) Schlegelmilch, plate 2, figs 1, 2 . 
1980 Tragophylloceras numismale (Quenstedt) Schlatter, plate 1, fig. 1a, b.

Type specimen. The original of Quenstedt (1845, plate 6, fig. 5a, b) was designated lectotype by Buckman (1912, p. viii).

Discussion. Full synonymy and description can be found in Howarth \& Donovan (1964, p. 295).

Stratigraphical horizon. Howarth \& Donovan (1964) noted that in well-dated north-west European localities, the species is restricted to the lower part of the Jamesoni Zone.

Material. A specimen now numbered 1987/94 was described and figured by Höhne (1933) from Rønne Lervarefabrik (Grube Rønne-Lervareværk), and is now refigured (Plate 1, figs 3-6). It is $67 \mathrm{~mm}$ in diameter and wholly septate, lacking, as Höhne remarked, the body chamber and part of the phragmocone. Specimens numbered 1976/804[2, 3] (Plate 1, figs 1, 2) are identified as Tragophylloceras cf. numismale. They are parts of phragmocones, the larger being about $110 \mathrm{~mm}$ in diameter.

\section{Tragophylloceras sp.}

Fig. 4A

\section{Phylloceras heterophyllum numismale Quenstedt - Höhne, p. 56, plate 14, fig. 1.}

Höhne (1933) described and figured from Rønne Lervarefabrik (Grube Rønne-Lervareværk) a fragment of a smooth ammonite showing parts of typical Tragophylloceras suture lines. It does not appear to be among the specimens examined by us. This is apparently the Phylloceras listed from bed 11 of his section (Höhne 1933, p.11). It could be T. numismale as Höhne thought, but is not now considered to be specifically identifiable.

\section{Suborder Ammonitina Zittel 1884 Superfamily Psilocerataceae Hyatt 1867 Family Oxynoticeratidae Hyatt 1875}

\section{Genus Radstockiceras Buckman 1918}

For synonymy of the genus, see Donovan et al. (1981, p. 137).
Radstockiceras hechingense Schlatter 1980

Plate 1, figs 7-9; plate 2, figs 1, 2

1854 Ammonites oxynotus numismalis Oppel, p. 84, plate 2, fig. $10 \mathrm{a}-\mathrm{c}$.

1856 Ammonites oxynotus numismalis Oppel - Quenstedt, p. 119, plate 14, fig. 1.

1885 Ammonites oxynotus numismalis Oppel - Quenstedt, p. 289, plate 37, figs 1-7.

1920 Oxynoticeras Oppelii Schloenbach - Malling, p. 55.

1925 Metoxynoticeras numismale (Quenstedt) - Spath, p. 112 , footnote 4 .

1962 Metoxynoticeras complanosum (Simpson) Howarth, p. 105, plate 15, fig. 4a, b.

1976 Radstockiceras complanosum (Simpson) - Schlegelmilch, plate 23, fig. 3 (original of Quenstedt 1885, plate 37 , fig. 1 , refigured).

1980 Metoxynoticeras numismale (Oppel) - Schlatter, p. 50 , plate 1 , figs 4,5 .

1980 Radstockiceras hechingense Schlatter, p. 52.

Type. The original of Oppel (1854, plate 2, fig. 10a-c) is the holotype. It is no longer extant (Schlatter 1980, p. 51). Spath (1925) wrongly stated the original of Quenstedt (1885, plate 37, fig. 4) to be the lectotype.

Nomenclature. Schlatter (1980) pointed out that Ammonites oxynotus numismalis Oppel (1854) was, when published, a homonym of Ammonites heterophyllus numismalis Quenstedt (1845). He therefore proposed the new specific name hechingense for Oppel's (1854) species. Simpson's Am. complanatus (1843) was replaced on account of homonomy by his Am. complanosus (1855). The holotype of the latter species (Whitby Museum: no. 239) was first figured by Howarth (1962, plate 15, fig. 4a, b) but is now said to be lost (Schlatter 1980, p. 51).

The Bornholm examples agree well with Oppel's (1854) somewhat stylised drawing of the lost holotype and with Schlatter's (1980) photographic figures. The species is strongly compressed, the whorl thickness being about $25 \%$ of the diameter. The venter is fastigate rather than sharp as in some oxycones. On the body chamber of large individuals, the fastigate venter is lost, the whorl becomes thicker and the venter broadly rounded as shown by Quenstedt (1885, plate 37, fig. 3), a specimen with whorl height $110 \mathrm{~mm}$ and thickness $47 \mathrm{~mm}$. The ribbing persists to varying diameters on different individuals. The more nearly complete example from Bornholm (Plate 1, figs 7-9) is about $107 \mathrm{~mm}$ in diameter, retaining some of the body chamber, but much larger specimens are known from elsewhere. 
Fig. 4. Ammonites reproduced from Höhne (1933, plate 14, figs 1, 3-9); all are shown at natural size. The material has not been seen by us and is probably lost. A, Tragophylloceras sp. Rønne Lervarefabrik.

B, Tragophylloceras numismale (Quenstedt). Rønne Lervarefabrik.

C1, 2; D1, 2, Ammonite gen. et sp. indet. Rønne Lervarefabrik.

E1, 2, Ammonite gen. et. sp. indet. Rønne Lervarefabrik.

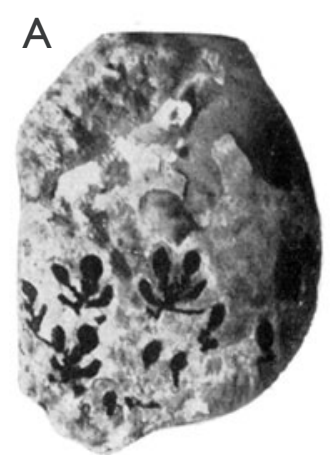

C1
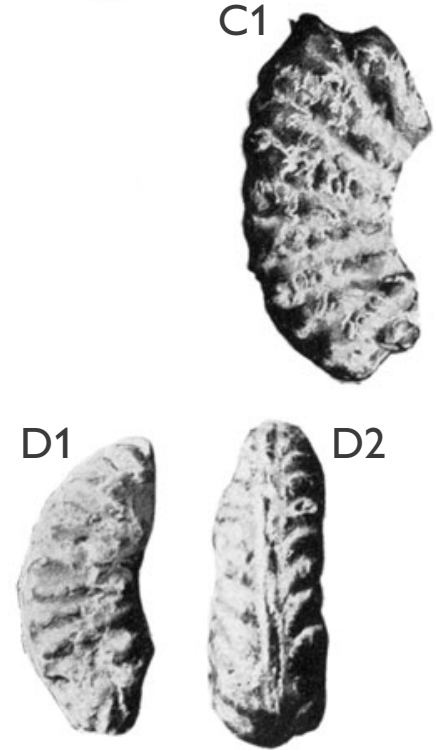

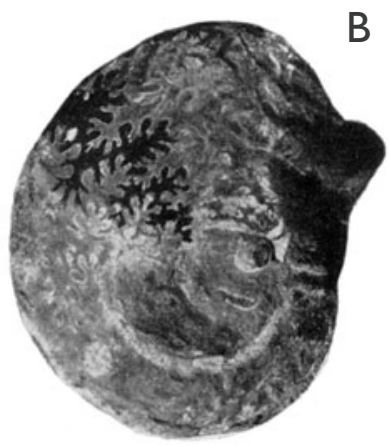

$\mathrm{C} 2$
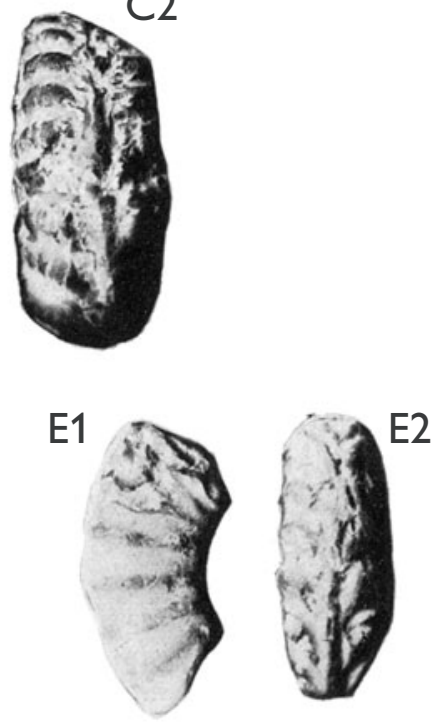

Stratigraphical horizon. The genus Radstockiceras probably ranges from the upper Raricostatum Zone to the mid-Davoei Zone (Donovan 1994). In the type Pliensbachian in southern Germany, it is almost restricted to the Polymorphus Subzone (Schlatter 1980, p. 52; table 2) but in northern Germany it seems to range through much of the Jamesoni Zone and possibly into the Ibex Zone (Hoffmann 1982, p. 152). It is not, therefore, a good indicator of stratigraphical horizon.

Material. Nos 1976/804[1], 1976/80, both from Rønne Lervarefabrik (Ny Østre Lergrav, Rønne).

\section{Family Eoderoceratidae Spath 1929}

\section{Genus Paramicroderoceras Dommergues et al. 1994}

It was previously noted by Donovan (1990, p. 258-259) that a number of evolute, bituberculate species have been commonly, but wrongly, referred to Microderoceras by continental authors. Donovan (1990) then placed them in Tetraspidoceras Spath 1926, as did Spath himself (e.g. Spath 1938, p. 5, fig. 1a). However, Tetraspidoceras as defined by the type species, Am. quadrarmatus Dumortier, has inner whorls with the umbilicus only about $35 \%$ of the diameter, ornamented with numerous fine ribs and pairs of small tubercles at intervals. The evolute, strongly tuberculate form is only developed on the body chamber. In contrast, the forms now under discussion show little, if any, change of shell form or ornament with growth. Dommergues et al. (1994, p. 36) have also pointed out that Tetraspidoceras is inappropriate for these species and have proposed the new genus Paramicroderoceras for them.

\section{Paramicroderoceras fila (Quenstedt 1884)}

Plate 2, figs 10-12

1884 Ammonites armatus fila Quenstedt, p. 205, plate 25 , fig. 7 ; plate 26 , figs 2,3 . 
1976 Microderoceras fila (Quenstedt) - Schlegelmilch, plate 24, fig. 4 (Quenstedt 1884, plate 25, fig. 7 refigured).

1980 Microderoceras fila (Quenstedt) - Schlatter, p. 54, plate 2 , fig. 2 .

Nomenclature. The status of Quenstedt's 'trinomina' is doubtful. Hölder (1958, p. 22) has stated that this name had not been previously used. As it has been employed as a species name by authors it is retained here.

Type. The original of Quenstedt (1884, plate 25, fig. 7) was refigured by Schlegelmilch (1976, plate 24, fig. 4) and stated to be lectotype. It is in the geological collections at the University of Tübingen, Germany.

Discussion. The single example from Bornholm agrees well with the lectotype. It is a phragmocone $100 \mathrm{~mm}$ in diameter. The last preserved part of the shell has been damaged by injury during life. The figured examples attributed to this species are all phragmocones, the later whorls and body chamber being unknown. Am. armatus bimacula Quenstedt (1884, p. 207, plate 26, fig. 4; a 'neotype' was figured by Schlegelmilch 1976, plate 24, fig. 3) differs little from $\mathrm{Am}$. arm. fila except by greater whorl thickness. The two names are probably to be considered as synonyms.

Stratigraphical horizon. Schlatter (1980) reported the species from the Jamesoni Zone, near the junction of the Taylori and Polymorphus subzones, and Hoffmann (1982, p. 156, plate 12, figs 1, 2a, b) recorded similar forms as probably from the lower part of the Jamesoni Zone. Such a horizon agrees well enough with other Bornholm material, but the genus is long-ranging and therefore not a very good stratigraphical indicator.

Material. One specimen, 1987/93, from Rønne Lervarefabrik (Ny Østre Lergrav, Rønne).

\section{Paramicroderoceras? sp. indet.}

Plate 2, fig. 13

?1920 Aegoceras armatum Sowerby var. nodofissus Quenstedt - Malling, p. 55.

A single specimen, 1976/806, from Ny Østre Lergrav, Rønne, is the internal mould of a fragment of a septate whorl. It has a compressed, flat-sided whorl section, and strong ribs, possibly bituberculate, each pair separated by three or four weaker ribs. It bears some resemblance to Hyperderoceras planarmatus (Quenstedt) in Schlegelmilch (1976, plate 27, fig. 2). That species is the type species of Parahyperderoceras Schlatter (1980, p. 62) which Schlatter regarded as a subgenus of Hyperderoceras Spath, but which Dommergues (1987, p. 99) regarded as a synonym of Epideroceras (Coeloderoceras). In view of the fragmentary nature of the present specimen further discussion seems unhelpful.

Stratigraphical horizon. Schlatter (1980, plate 3, fig. 7) illustrated a somewhat similar form, with stronger and coarser ornament, from the late Taylori/earliest Polymorphus Subzone.

Material. 1976/806 from Rønne Lervarefabrik (Ny Østre Lergrav, Rønne).

\section{Family Coeloceratidae Haug 1910}

\section{Genus Coeloceras Hyatt 1867}

\section{Coeloceras grenouillouxi (d'Orbigny 1844)}

Plate 2, figs 6-9

1844 Ammonites grenouillouxi d'Orbigny, p. 307, plate 96, figs $1-6$.

1914 Aegoceras pettos Malling, p. 269.

1920 Aegoceras pettos Quenstedt - Malling, p. 55.

1980 Coeloceras grenouillouxi (d'Orbigny) - Schlatter, p. 73 , plate 6 , figs $1-3$.

1994 Coeloceras grenouillouxi (d'Orbigny) - R. Mouterde and J.-L. Dommergues in Fischer, p. 85, plate 22 , figs 4 (lectotype), 5a, b, 6, 7a, b.

Types. There are 15 surviving syntypes in the d'Orbigny collection of which one was designated lectotype, and figured, by Schlatter (1980, p. 73, plate 6, fig. 1). The lectotype and three other syntypes were also figured by R. Mouterde and J.-L. Dommergues (in: Fischer 1994).

Discussion. The single specimen from Bornholm agrees well with the lectotype. Schlatter (1980), studying the German material from the type area of C.pettos, treated C. grenouillouxi as separate from C. pettos. However, Dommergues \& Mouterde (1978, p. 346), reviewing abundant material from the type locality of $C$. grenouillouxi at Cottards (Cher), France, concluded that the assemblage showed considerable variability and they regarded C. grenouillouxi as a synonym of C. pettos. 
R. Mouterde and J.-L. Dommergues (in: Fischer 1994, p. 85) also thought that the two 'species' "pourraient n'être en réalité que deux morphes de la même espèce". Dommergues (1994) has recently claimed to recognise dimorphism in the genus.

Stratigraphical horizon. In southern Germany, southern England and Burgundy, Coeloceras is found in the upper part of the Jamesoni Subzone. Dommergues (1987, p. 25) recognised a horizon of Evolutus (Pettos) and Page (2003, this volume) a Pettos Zonule. It is likely that this horizon is present in Bornholm.

Material. No. 1987/83 from Rønne Lervarefabrik (Ny Østre Lergrav, Rønne) (1987/92 is the impression of $1987 / 83)$. This may be the specimen recorded as Aegoceras pettos by Malling (1914) from Rønne Lervarefabrik (described by him as Rønne Lervarefabriks ny Grav, his locality 5; Fig. 1).

\section{Genus Apoderoceras Buckman 1921}

\section{Apoderoceras aculeatum (Simpson 1843)}

Plate 2, figs 3-5

1843 Ammonites aculeatus Simpson, p. 27.

1843 Ammonites marshallani Simpson, p. 24.

1855 Ammonites aculeatus Simpson, p. 66.

1855 Ammonites marshallani Simpson, p. 62.

1876 Aegoceras aculeatus (Simpson) - Blake, p. 278, plate 7 , fig. 4.

1880 Aegoceras leckenbyi Wright, plate 30, figs 1-7.

1882 Aegoceras leckenbyi Wright, p. 344.

1884 Ammonites aculeatus Simpson, p. 99.

1884 Ammonites marshallani Simpson, p. 94.

1913 Apoderoceras aculeatum (Simpson) - Buckman, plate $72 \mathrm{~A}-\mathrm{C}$.

1954 Apoderoceras aculeatum (Simpson) - Donovan, p. 35 .

1962 Apoderoceras aculeatum (Simpson) - Howarth, p. 109 , plate 15 , fig. $5 \mathrm{a}, \mathrm{b}$.

Nomenclature. Simpson's (1843) unillustrated specimen was first figured by Blake (1876), and later, photographically, by Buckman (1913). Ammonites marshallani was not figured until Howarth (1962) who regarded it as a synonym of aculeatum. Ammonites decussatum Simpson (1843, p. 25) is probably also a synonym (Howarth 1962, p. 109). The species is somewhat vari- able and several other specific names of authors are probably synonyms.

Type. The holotype of Apoderoceras aculeatum is lost. A paratype (Whitby Museum: no. 177) was figured by Buckman (1913, plate 72A-C).

Discussion. The species when complete is about 300 $\mathrm{mm}$ in diameter. The Coeloceras-like innermost whorls are succeeded by a finely ribbed or striate, tuberculate, stage which gives way to a body chamber ornamented with stout ribs bearing ventro-lateral tubercles, (e.g. Hoffmann 1982, plate 37). The single specimen from Bornholm is a typical example of the inner whorls, only $79 \mathrm{~mm}$ in diameter.

Stratigraphical horizon. In northern Europe Apoderoceras occurs in the Taylori Subzone. The present species probably comes from this subzone.

Material. M 1933/68, from Rønne Lervarefabrik (Ny Østre Lergrav, Rønne).

\section{Family Phricodoceratidae Spath 1938}

\section{Genus Pbricodoceras Hyatt 1900}

\section{Phricodoceras taylori (J. de C. Sowerby 1826)}

Plate 4, figs 9-13; Plate 6, figs 3-5

1826 Ammonites Taylori J. de C. Sowerby, p. 23, plate 514, fig. 1.

1843 Ammonites cornutus Simpson, p. 31.

1855 Ammonites cornutus Simpson, p. 71.

1884 Ammonites Taylori Sowerby - Simpson, p. 105.

1911 Phricodoceras cornutum Simpson - Buckman, plate 32 .

1933 Aegoceras taylori Sowerby var. bornholmiensis Höhne, p. 52, plate 12, figs 1-4, 6, 7.

1961 Phricodoceras taylori (J. de C. Sowerby) - Dean et al., plate 68 , fig. $5 \mathrm{a}, \mathrm{b}$.

1976 Phricodoceras cornutum (Simpson) - Schlegelmilch, plate 28 , fig. 1 ?

Types. Sowerby's (1826) figured specimen and presumed holotype of Ammonites taylori is lost. It was from a boulder in glacial till at Happisburgh, Norfolk, England.

There are four syntypes of Höhne's (1933) var. bornbolmiensis from Rønne Lervarefabrik (Rønne Lervare- 
fabriks Ny Grav). It has not been possible to trace the originals. They were probably lost from the collections at the University of Greifswald during World War Two. The replicas seen by us are numbered as follows:

1976/809 = original of Höhne 1933, plate 12, figs 1, 3 1976/810 = original of Höhne 1933, plate 12, fig. 2 1976/811 = original of Höhne 1933, plate 12, figs 6, 7 1976/812 = original of Höhne 1933, plate 12, fig. 4

Note that some of Höhne's illustrations have been trimmed, and that the figures are not half natural size as stated on the plate. The replicas are figured here as Plate 4, figs 9-13 and Plate 6, figs 3-5.

The original of Höhne's Exemplar 3, i.e. of his plate 12, figs 6, 7 (replica no. 1976/811), is here designated the lectotype of Aegoceras taylori Sowerby var. bornholmiensis Höhne. It is refigured here (Plate 6, figs 3-5).

Nomenclature. There are two common forms of small Phricodoceras, one of which has strong tubercles at the ventral ends of the ribs; tubercles half-way along the ribs, if present, die out at a small size (c. $20 \mathrm{~mm}$ ). This is P. taylori. Ammonites cornutus Simpson 1843 is a synonym, as Simpson himself recognised in 1884 (p. 105). The other form has the inner tubercles persisting to a larger size, and this is Ammonites quadricornutus Simpson 1855 (holotype figured by Buckman 1911, plate 32). Unfortunately, Schlegelmilch in his picturebook of Lias ammonites has confused the two forms and illustrates $P$. quadricornutum under the name of P. taylori (Schlegelmilch 1976, plate 27, fig. 3) and $P$. taylori as P. cornutum (Schlegelmilch 1976, plate 28, fig. 1).

Phricodoceras costatum (Quenstedt) as figured by Schlatter (1980, p. 77, plate 6, fig. 4) appears close to P. taylori. Schlatter (1980, p. 78) refers the bituberculate species from Pliensbach to P. nodosum (Quenstedt). However, Am. Taylori nodosus (Quenstedt 1846, p. 136) was, when proposed, a junior homonym of $A m$. nodosa de Roissy and at least two other prior uses. It appears to the present writers that Quenstedt's nodosus can be accommodated in Simpson's quadricornutus.

Aegoceras taylori Sowerby var. bornholmiensis of Höhne (1933) is here considered a synonym of P. taylori.

Discussion. Phricodoceras includes both small species (taylori, quadricornutum) and large ones (lamellosum d'Orbigny, non J. de C. Sowerby) and is probably dimor- phic, as noted by Dommergues (1978) who interpreted Ammonites lamellosus d'Orbigny as the macroconch of P. taylori. Only the small forms (microconchs) have been reported from Bornholm. They are typical examples of P. taylori.

Stratigraphical horizon. In Tethyan areas, Phricodoceras has a long stratigraphical range, from the Upper Sinemurian to the Upper Pliensbachian. In Northwest Europe, however, it characterises the lowermost part of the Jamesoni Zone (Taylori Subzone), and it is likely to mark this horizon in Bornholm. In Burgundy (Dommergues 1987) and in southern Germany (Schlatter 1980), Phricodoceras occurs mainly above Apoderoceras (Taylori and Nodogigas zonules of Page 2003, this volume), and it is possible that both these levels are represented in Bornholm.

Material. 1976/809-812, replicas of Höhne's (1933) four specimens referred to above, from bed 53 in the section at Rønne Lervarefabrik recorded by Höhne (1933, p. 11, 12); 1987/91 from Rønne Lervarefabrik (Ny Østre Lergrav, Rønne).

\section{Family Polymorphitidae Haug 1887}

\section{Genus Platypleuroceras Hyatt 1867}

\section{Platypleuroceras brevispina (J. de C. Sowerby 1827)}

Plate 3, figs 1-6

1827 Ammonites brevispina J. de C. Sowerby, p. 106, plate 556, fig. 1 (fig. 2 cited in the text in error).

1845 Ammonites natrix rotundus (var. $\alpha$ ) Quenstedt, p. 85 , plate 4 , fig. $17 \mathrm{a}-\mathrm{c}$.

1845 Ammonites natrix oblongus (var. ß) Quenstedt, p. 85 , plate 4 , fig. $16 \mathrm{a}-\mathrm{c}$.

1880 Aegoceras brevispina (J. de C. Sowerby) - Wright, plate 32, figs 2, 3 .

1882 Aegoceras brevispina (J. de C. Sowerby) - Wright, p. 361.

1885 Ammonites amplinatrix Quenstedt, p. 257, plate 32, fig. 7.

1925 Platypleuroceras brevispinoides Tutcher \& Trueman, p. 649, plate 40, fig. 2.

1954 Platypleuroceras brevispina (J. de C. Sowerby) Donovan, p. 36.

1961 Platypleuroceras brevispina (J. de C. Sowerby) Dean et al., plate 69, fig. 1. 
1976 Platypleuroceras brevispina (J. de C. Sowerby) Schlegelmilch, plate 29, figs 3, 4.

1980 Platypleuroceras brevispina (Sowerby 1827) Schlatter, p. 95, plate 8, fig. 1 (with synonymy).

1980 Platypleuroceras oblongum (Quenstedt 1845) Schlatter, p. 98, plate 8, fig. 2; plate 9, fig. 1 (with synonymy).

1980 Platypleuroceras rotundum (Quenstedt 1845) Schlatter, p. 101, plate 9, figs 2, 3 (with synonymy).

Type. J. de C. Sowerby's only specimen, regarded as the holotype, was refigured by Wright (1880, plate 32, figs 2, 3), Dean et al. (1961, plate 69, fig. 1) and by Schlegelmilch (1976, plate 29, fig. 3). It is in the British Museum (Natural History) no. 43915. Details of the types of Ammonites natrix oblongus, Ammonites natrix rotundus and Platypleuroceras brevispinoides are given by Schlatter (1980).

After studying abundant material, Dommergues (1987, p. 141) concluded that the other names included in the above synonymy had been applied to forms which fall within the range of variation of $P$. brevispina.

The specimens from Bornholm are typical of the species. Dommergues (1987, p. 141, 142) believed the species to be dimorphic. The Bornholm examples are all macroconchs according to Dommergues' interpretation, complete with body chambers at diameters of about $100 \mathrm{~mm}$.

Stratigraphical horizon. The species characterises the Brevispina Subzone of the Jamesoni Zone, and ranges throughout the subzone according to Schlatter (1980, table 2). In Burgundy, Dommergues (1987, p. 29) regarded the species as characteristic of the lower part of the subzone, replaced by species of the group of $P$. submuticum in the upper part.

Material. Nos 1886/224 and 1976/803, both from Sose Odde; 1976/702 from Rønne Lervarefabrik (Ny Østre Lergrav, Rønne).

\section{Platypleuroceras submuticum (Oppel 1856)}

Plate 4, figs 1-6; Plate 6, figs 8-10

1854 Ammonites natrix oblongus Quenstedt - Oppel, p. 35 , plate 1 , fig. $5 \mathrm{a}, \mathrm{b}$.

1856 Ammonites submuticus Oppel, p. 278.

1980 Platypleuroceras submuticum (Oppel) - Schlatter, p. 103, plate 9, fig. 5; plate 10 , figs 1,2 (with synonymy).
1980 Platypleuroceras enzenharti Schlatter, p. 107, plate 11, figs 1, 2 (holotype).

1987 Platypleuroceras submuticum (Oppel) - Dommergues, p. 142, plate 9, figs 1-13.

Type. The holotype is the ammonite figured by Oppel (1854) as Quenstedt's Am. natrix oblongus and renamed by him in 1856. It is in the Bayerische Staatssammlung at München no. AS VIII 156 and was refigured by Schlatter (1980, plate 9, fig. 5). The holotype of Platypleuroceras enzenharti is in the Staatliches Museum für Naturkunde, Stuttgart, no. 23567.

Dommergues (1987) has discussed the characters and variability of the species. He regarded $P$. enzenharti Schlatter as a variant of P. submuticum. Compared with $P$. brevispina the species is typically compressed with flat-sided whorls and closer ribbing. The inner row of spines is absent. The examples from Bornholm are typical. By analogy with P. brevispina they are presumably macroconchs. No. 1975/1491 (Plate 6, figs 8-10) is still septate at a diameter of about $120 \mathrm{~mm}$.

Stratigraphical horizon. The species is found in the upper part of the Brevispina Subzone (Schlatter 1980, table 2; Dommergues 1987, p. 29).

Material. Nos 1975/1491, 1987/94, both from Rønne Lervarefabrik (Rønne Lervarefabriks Ny Grav). No. 1976/808 from the same locality, an impression seen in side view only, may belong to the species.

\section{Platypleuroceras caprarium (Quenstedt 1856)}

Plate 3, figs 7-9; Plate 5, figs 1-21

1856 Ammonites caprarius Quenstedt, p. 131, plate 16, fig. 1.

1884 Ammonites caprarius Quenstedt, p. 243, plate 30, figs 37-42.

1920 Aegoceras caprarius (Quenstedt) - Malling, p. 55.

1933 Aegoceras m.f. Valdani-Maugenesti Höhne, p. 54, plate 13 , figs 3?, 4, 5.

1976 Platypleuroceras caprarium (Quenstedt) - Schlegelmilch, p. 63, plate 29, fig. 5 (neotype).

1977 Platypleuroceras caprarium (Quenstedt) Schlatter, p. 10, plate 2, fig. 1a, b.

1980 Polymorphites caprarius (Quenstedt) - Schlatter, p. 92.

1982 Platypleuroceras caprarium (Quenstedt) Hoffmann, p. 194, plate 20, figs 1a, b, 2a, b, 3a, b, 4, 5a-d, 6 . 
1987 'Platypleuroceras' caprarium (Quenstedt) Dommergues, p. 152, plate 6, figs 45-48; plate 7 , figs 1-4.

Type. The specimen figured by Quenstedt (1856) is lost. A neotype was designated and figured by Schlegelmilch (1976).

Discussion. The species is characterised by compressed whorls, close, regular ribbing, and strong ventral ornament. There are small but equally prominent inner and outer spines. The Bornholm examples are typical of the species. Plate 13, fig. 3 in Höhne (1933) is the side view only of a specimen which we have not seen. It may belong to P. caprarium.

Bornholm individuals with body chamber are 55-60 $\mathrm{mm}$ in diameter when complete; specimen no. 1987/86 is about $61 \mathrm{~mm}$ in diameter with three-quarters of a whorl of body chamber, and an unnumbered specimen (Plate 5, figs 7-9) has a body chamber of about three-quarters of a whorl at $58 \mathrm{~mm}$ diameter and is complete with the aperture of the shell.

The species is smaller than later species of Platypleuroceras. Dommergues (1987, p. 152) regarded $P$. caprarium as a macroconch and illustrated examples ranging from about $45 \mathrm{~mm}$ to $84 \mathrm{~mm}$ in diameter. He illustrated as $P$. (m) sp. 3 (Dommergues 1987, plate 6, figs 23-30) specimens ranging from 29 to $44 \mathrm{~mm}$ diameter which he thought might be the microconchs of the species. The Bornholm examples would all be macroconchs according to Dommergues' (1987) definition.

Stratigraphical horizon. Detailed collecting of the type Pliensbachian by Schlatter (1980) showed the species to be the earliest species of Platypleuroceras, though occurring wholly above the range of Phricodoceras. Hoffmann (1982, p. 260) recorded it below, as well as in association with, Phricodoceras in north Germany.

Material. Nos 1987/86-90 from Rønne Lervarefabrik (Ny Østre Lergrav, Rønne). The specimen 1987/87 is a replica of that figured by Höhne (1933, plate 13, figs 4, 5). Note that Höhne's figs 4 and 5 are 0.7 and 0.86 respectively of true size, not 0.5 as stated. No. 1831 (2 complete specimens and a body chamber fragment) from Rønne Lervarefabrik (Rønne Lervarefabriks nye Grav). No. 2021 from the same locality (?). Two unnumbered complete specimens.
Platypleuroceras spp. indet.

Plate 4, fig. 7; Plate 6, fig. 6

1933 Aegoceras m.f. Valdani-Maugenesti d'Orbigny Höhne, p. 54, plate 13, figs 1, 2.

Höhne (1933) illustrated in side view only two small Platypleuroceras, the originals of which have not been seen by us. The material examined includes a (body chamber?) fragment, 1976/807, from Rønne Lervarefabrik (Ny Østre Lergrav, Rønne), and an impression, 1976/813 (Plate 4, fig. 7), found loose on the beach north of Rønne. None of these examples is considered to be identifiable at species level.

\section{Genus Uptonia Buckman 1897}

\section{Uptonia lata (Quenstedt) (sensu Schlatter 1980)}

Plate 6, figs 1,2

1980 Uptonia ex gr. lata (Quenstedt) - Schlatter, p. 114 , plate 13 , fig. 1 (with synonymy)

1980 Uptonia confusa (Quenstedt) - Schlatter, p. 114, plate 13 , figs $2 \mathrm{a}, \mathrm{b}, 3 \mathrm{a}$, b; plate 14 , fig. 1a, b (with synonymy).

1987 Uptonia lata (Quenstedt) (sensu Schlatter) Dommergues, p. 133, plate 10, figs $1-5$.

Type. Quenstedt's (1845) figured specimen is not known to exist.

Nomenclature. Quenstedt (1845, p. 88; 1849, plate 4, fig. 1) described and figured Ammonites jamesoni var. latus. His illustration is of a fragment of an outer whorl which cannot be satisfactorily interpreted. Dommergues (1987) has adopted the name in the interpretation of Schlatter (1980).

The species is distinguished from U.jamesoni (J. de C. Sowerby), as interpreted by the neotype designated by Donovan \& Forsey (1973, p. 12, plate 4, fig. 3a, b), by having fewer ribs throughout, and stronger ornament on the body chamber. Dommergues (1987, p. 115, fig. 28) regarded the species as later than $U$. jamesoni in his evolutionary lineage.

The species is large. Schlatter (1980, plate 14, fig. 1) figured (as $U$. aff. confusa) a wholly septate example $117 \mathrm{~mm}$ in diameter, and Dommergues (1987, plate 10, figs 1,2) figured one still septate at $132 \mathrm{~mm}$ diameter. The Bornholm specimen is smaller, with about threeeighths of a whorl of body chamber at a diameter of 
about $120 \mathrm{~mm}$, and inner whorls mostly preserved as an impression.

Stratigraphical horizon. In the type Pliensbachian the species occurs throughout the Jamesoni Subzone and just ranges into the succeeding Ibex Zone (Schlatter 1980).

Material. No. 1987/85, recorded only as from Bornholm Island.

\section{Uptonia sp. indet.}

Plate 6, fig. 7

A septate whorl fragment from Rønne Lervarefabrik (Ny Østre Lergrav, Rønne), no. 1976/801, is not considered to be specifically identifiable.

\section{Family Acanthopleuroceratidae}

\section{?Acantbopleuroceras sp. indet.}

Plate 4, fig. 8

?1920 Aegoceras Maugenesti d'Orbigny - Malling, p. 55.

An incompletely preserved ammonite, no. 1987/84, differs from the species of Platypleuroceras and Uptonia recorded above in having nearly smooth inner whorls, followed by coarse, blunt ribs. It bears some resemblance to forms figured, for example by Schlatter (1980, plate 16, fig. 3), as Acanthopleuroceras maugenesti (d'Orbigny). If this identification is correct it indicates the Ibex Zone, Valdani Subzone. The locality is recorded only as Bornholm Island.

\section{Family Liparoceratidae}

\section{Genus Beaniceras s.s. Buckman 1913}

\section{Beaniceras centaurus (d'Orbigny 1844)}

1844 Ammonites centaurus d'Orbigny, p. 266, plate 76, figs 3-6.

1909 Aegoceras centaurus d'Orbigny var. bornbolmiensis Malling \& Grönwall, p. 288, plate 11, figs 9-11.

1918 Beaniceras senile Buckman, plate 126.

1919 Beaniceras centaurus (d'Orbigny) - Buckman, plate 146.
1924 Beaniceras senile Buckman, plate 126A.

1938 Beaniceras centaurus (d'Orbigny) - Spath, p. 107, plate 16, fig. 9a, b.

1938 Beaniceras centaurus (d'Orbigny) var. cherensis Spath, p. 108, plate 6, fig. 7a-c.

1938 Beaniceras centaurus (d'Orbigny) var. elegans Spath, p. 108, plate 6, fig. 8a, b; plate 16, fig. 9c, d.

1938 Beaniceras centaurus (d'Orbigny) var. subcrassa Spath, p. 108, plate 16, figs 8a, b.

1938 Beaniceras senile Buckman - Spath, p. 109, plate 15 , figs $2 \mathrm{a}, \mathrm{b}$.

1978 Beaniceras centaurus (d'Orbigny) - Dommergues \& Mouterde, plate 3, figs 11a-c, 12a-c, 13a-c.

1985 Androgynoceras (subgen. nov.) centaurus (d'Orbigny) - Phelps, plate 1, figs 14, 15a, b.

1994 Beaniceras centaurus (d'Orbigny) - J.-L. Dommergues and R. Mouterde in Fischer, p. 69, plate 23 , figs $7 \mathrm{a}-\mathrm{c}, 8 \mathrm{a}-\mathrm{c}, 9 \mathrm{a}, \mathrm{b}$ (syntypes figured).

Types. There are twenty specimens of Am. centaurus in the d'Orbigny collection (J.-L. Dommergues and R. Mouterde in: Fischer 1994, p. 69). No lectotype has been designated. The holotype of Beaniceras senile (original of Buckman 1918, plate 126) is in the British Geological Survey collection no. 47092. Aegoceras centaurus d'Orbigny var. bornholmiensis Malling \& Grönwall was evidently based on the single figured specimen which is therefore the holotype. We have not seen this specimen.

Discussion. Phelps (1985) regarded the species as belonging to a new (but unnamed) subgenus (of Androgynoceras). Pending the naming of such a subgenus, the species is here retained in Beaniceras.

D'Orbigny (1844) illustrated only the cadicone inner whorls. Spath (1938, p. 109) separated B. senile Buckman from $B$. centaurus on the basis of its contracted bodychamber with arched venter in contrast to the flatter venter of the preceding whorl. However, material from the type area figured by Dommergues \& Mouterde (1978) shows that in the adult, the body chamber, about half a whorl long and $20 \mathrm{~mm}$ diameter, ceases to expand with growth and corresponds with the form named $B$. senile by Buckman (1918).

Phelps (1985), who revised the stratigraphy and taxonomy of Beaniceras, figured (plate 1, fig. 14) as centaurus an ammonite which is indistinguishable from the holotype of $B$. senile, which he presumably regarded as a synonym.

Malling \& Grönwall (1909) described and figured as Aegoceras centaurus d'Orbigny var. bornholmiensis an ammonite from their locality at Stampen, Bornholm 
which is very similar to Beaniceras senile, and is therefore placed in synonymy. It should be noted, however, that if it is desired to uphold Buckman's (1924) species B. senile, then the name bornholmiensis has priority.

Stratigraphical horizon. Phelps (1985) recognised a Centaurus Zonule near the top of the Valdani Subzone, and this has been adopted by Page (2003, this volume).

Material. Malling and Grönwall's (1909) figured specimen has not been seen by us, and its present location is not known.

\section{Ammonite gen. et sp. indet.}

Fig. 4C1-2, D1-2

1933 Amaltheus cf. spinatus Bruguière - Höhne, p. 55, plate 14, figs 4-7.

Discussion. The whorl fragments were identified by Höhne (1933) as close to Amaltheus spinatus, i.e. Pleuroceras in modern nomenclature. If correct this would indicate the Domerian Stage, Spinatum Zone. However, the fragments do not look like Pleuroceras as far as can be seen from the poor illustration, reproduced here (Fig. 4). They appear to show bifurcating ribs, which do not occur in Pleuroceras, and do not show the interrupted keel characteristic of that genus. The V-shaped ribs arise from an umbilical tubercle, with thickened, forwardly curved outer ends. It is to be noted that while the specimen illustrated as fig. 4 in plate 14 (Höhne 1933) is shown with its anterior end upwards, the corresponding ventral view (fig. 5) is wrongly oriented, with the anterior end downwards.

There are several Jurassic and Cretaceous ammonite genera which have the characters described above, and it is not considered safe to identify these fragments from the figures.

Material. Two whorl fragments figured by Höhne (1933), from Rønne Lervarefabrik (Rønne Lervareverk). Stated to be in the Bornholm Museum at Rønne. This material has not been seen by us.

\section{Ammonite gen. et sp. indet.}

Fig. 4E1-E2

1933 Amaltheus cf. spinatus Bruguière - Höhne, p. 55, plate 14 , figs 8,9
Material. A whorl fragment found by Höhne in Bed 3 of Rønne Lervarefabrik (Höhne 1933, p. 11); 66.4-69.4 m in Fig. 2.

Discussion. This whorl fragment was also wrongly identified by Höhne (1933) as Amaltheus. It has straight ribs each of which appears to bear three tubercles or spines. It is not considered to be identifiable from the figures.

\section{Acknowledgements}

We thank Walter Kegel Christensen for assistance in locating some of the specimens, Jan Aagaard for photography, Merete Vesterager for word processing, Christian Hagen for drafting, and Kevin N. Page and Lars $\mathrm{H}$. Nielsen for reviewing the manuscript.

\section{References}

Blake, J.F. 1876: Cephalopoda. In: Tate, R. \& Blake, J.F. (eds): The Yorkshire Lias, 261-330. London: John van Voorst.

Buckman, S.S. 1909-1930: Yorkshire type ammonites $(\mathbf{1}, \mathbf{2})$ and Type ammonites (3-7), 790 plates. London: Wheldon \& Wesley. Specific volumes/parts cited in this paper:

Buckman, S.S. 1911: Yorkshire type ammonites 1 (parts 3-5). Buckman, S.S. 1912: Yorkshire type ammonites 1 (parts 6-8). Buckman, S.S. 1913: Yorkshire type ammonites 2 (parts 9-11).

Buckman, S.S. 1918: Yorkshire type ammonites 2 (parts 15-17).

Buckman, S.S. 1919: Yorkshire type ammonites 2 (part 18); Type ammonites 3 (parts 19, 20).

Buckman, S.S. 1924: Type ammonites 5 (parts 44-49).

Dean, W.T., Donovan, D.T. \& Howarth, M.K. 1961: The Liassic ammonite zones and subzones of the north-west European province. Bulletin of the British Museum (Natural History), Geology 4, 435-505.

Dommergues, J.-L. 1978: Un cas de dimorphisme sexuel chez une ammonite carixienne Phricodoceras taylori (J. de C. Sowerby 1826) Eoderoceratidae Spath 1929. Bulletin Scientifique de Bourgogne 31, 41-45.

Dommergues, J.-L. 1987: L'évolution chez les Ammonitina du Lias moyen (Carixien, Domerien basal) en Europe occidentale. Documents des Laboratoires de Géologie de Facúlte des Sciences de Lyon 98, 272 pp.

Dommergues, J.-L. 1994: The Jurassic ammonite Coeloceras: an atypical example of dimorphic progenesis elucidated by cladistics. Lethaia 27, 143-152

Dommergues, J.-L. \& Mouterde, R. 1978: Les faunes d'ammonites du Carixien inférieur et moyen du gisement des Cottards (Cher). Géobios 11, 345-365. 
Dommergues, J.-L., Ferretti, A. \& Meister, C. 1994: Les faunes d'ammonites du Sinémurien de l'Apennin Central (Marches et Toscane, Italie). Bollettino della Società Paleontologica Italiana 33, 13-42.

Donovan, D.T. 1954: Synoptic supplement to T. Wright's 'Monograph on the Lias ammonites of the British Islands' (1878-86), 54 pp. London: Palaeontographical Society.

Donovan, D.T. 1990: Sinemurian and Pliensbachian ammonite faunas of central Italy. In: Pallini, G. et al. (eds): Atti II Convegno Internazionale: 'Fossili, Evoluzione, Ambienti', Pergola 1987, 253-262.

Donovan, D.T. 1994: Evolution in some early Jurassic ammonites: Asteroceratinae, Oxynoticeratidae and related forms. In: Pallini, G. (ed.): Proceedings of the 3rd Pergola International Symposium 'Fossili, Evoluzione, Ambienti', Palaeopelagos Special Publication 1, 383-396. Rome: Università 'La Sapienza'.

Donovan, D.T. \& Forsey, G.F. 1973: Systematics of Lower Liassic Ammonitina. University of Kansas Paleontological Contributions Paper 64, 18 pp.

Donovan, D.T., Callomon, J.H. \& Howarth, M.K. 1981: Classification of the Jurassic Ammonitina. In: House, M.R. \& Senior, J.R. (eds): The Ammonoidea. Systematics Association Special Volume 18, 101-155.

d'Orbigny, A. 1844: Paléontologie française. Terrains jurassiques. I. Céphalopodes, 193-312. Paris: Masson.

Fischer, J.-C. (ed.) 1994: Révision critique de la Paléontologie française d'Alcide d'Orbigny. Volume I. Céphalopodes jurassiques, $340 \mathrm{pp}+$ facsimile of d'Orbigny 1842-1851. Paris: Masson.

Gravesen, P., Rolle, F. \& Surlyk, F. 1982: Lithostratigraphy and sedimentary evolution of the Triassic, Jurassic and Lower Cretaceous of Bornholm, Denmark. Danmarks Geologiske Undersøgelse Serie B 7, 51 pp.

Gry, H. 1969: Megaspores from the Jurassic of the island of Bornholm. Meddelelser fra Dansk Geologisk Forening 19, 69-89.

Hoffmann, K. 1982: Die Stratigraphie, Paläogeographie und Ammonitenführung des Unter-Pliensbachium (Carixium, Lias gamma) in Nordwest-Deutschland. Geologisches Jahrbuch Reihe A 55, 442 pp.

Höhne, R. 1933: Beiträge zur Stratigraphie, Tektonik und Paläogeographie des südbaltischen Rhät-Lias, insbesondere auf Bornholm. Abhandlungen aus dem geologisch-paläontologischen Institut der Universität Greifswald 12, 1-105.

Hölder, H. 1958: Vorschläge für die Behandlung von F.A. Quenstedt's Nomenklatur. Paläontologische Zeitschrift 32, $18-23$.

Howarth, M.K. 1962: The Yorkshire type ammonites and nautiloids of Young and Bird, Phillips, and Martin Simpson. Palaeontology 5, 93-136.

Howarth, M.K. \& Donovan, D.T. 1964: Ammonites of the Liassic Family Juraphyllitidae in Britain. Palaeontology 7, 286-305.

Koppelhus, E.B. \& Nielsen, L.H. 1994: Palynostratigraphy and palaeoenvironments of the Lower to Middle Jurassic Baga Formation of Bornholm, Denmark. Palynology 18, 139-194.

Larsen, O.H. \& Friis, H. 1991: Petrography, diagenesis and porewater evolution of a shallow marine sandstone (Hasle
Formation, Lower Jurassic, Bornholm, Denmark). Sedimentary Geology 72, 269-284.

Lundgren, B. 1879: Bidrag til kännedomen om Juraformationen på Bornholm. Festskrift till Universitet i Köpenhamn vid dess Jubileum 1879, 29 pp. Lund: Lunds Universitet.

Malling, C. 1911: Hasle-Sandstenens alder. Meddelelser fra Dansk Geologisk Forening 3, 629-631.

Malling, C. 1914: De Jespersenske Buelag i Lias paa Bornholm. Meddelelser fra Dansk Geologisk Forening 4, 265-270.

Malling, C. 1920: Den marine Lias og Wealden-Aflejringer paa Bornholm. Meddelelser fra Dansk Geologisk Forening 5 , 55-57.

Malling, C. \& Grönwall, K.A. 1909: En Fauna i Bornholms Lias. Meddelelser fra Dansk Geologisk Forening 3, 271-316.

Michelsen, O., Nielsen, L.H., Johannessen, P.N., Andsbjerg, J. \& Surlyk, F. 2003: Jurassic lithostratigraphy and stratigraphic development onshore and offshore Denmark. In: Ineson, J.R. \& Surlyk, F. (eds): The Jurassic of Denmark and Greenland. Geological Survey of Denmark and Greenland Bulletin 1, 147-216 (this volume).

Moberg, J.C. 1888: Om Lias i Sydöstra Skåne. Sveriges Geologiske Undersökning. Serie C 99, 86 pp.

Oppel, A. 1854: Der mittlere Lias Schwabens. Jahresheft des Vereins für Vaterländische Naturkunde in Württemberg $\mathbf{1 0}$ 39-136. [Usually cited as 1853; Hoffmann (1982, p. 351) however, stated that it was printed in 1854].

Oppel, A. 1856-1858: Die Juraformation Englands, Frankreichs und des südwestlichen Deutschlands, nach ihren einzelnen Gliedern eingetheilt und verglichen. Jahresheft des Vereins für Vaterländische Naturkunde in Württemberg 12-14, 857 pp. Stuttgart: Ebner \& Seubert. [Oppel's work appeared in issues 2, 3 of volume 12, issues 2, 3 of volume 13 and issues 2, 3 of volume 14 , with the corresponding page numbers 1856: p. 1-438; 1857: p. 439-694; 1858: p. 695-857].

Page, K.N. 2003: The Lower Jurassic of Europe: its subdivision and correlation. In: Ineson, J.R. \& Surlyk, F. (eds): The Jurassic of Denmark and Greenland. Geological Survey of Denmark and Greenland Bulletin 1, 23-59 (this volume).

Phelps, M.C. 1985: A refined ammonite biostratigraphy for the middle and upper Carixian (Ibex and Davoei zones, Lower Jurassic) in north-west Europe and stratigraphical details of the Carixian-Domerian boundary. Geobios 18, 321-362.

Quenstedt, F.A. 1845-1849: Petrefactenkunde Deutschlands. I. Die Cephalopoden, 580 pp. Tübingen: Fues.

Quenstedt, F.A. 1856: Der Jura [first part], 576 pp. Tübingen: Laupp.

Quenstedt, F.A. 1884: Die Ammoniten des Schwäbischen Jura. I. Der Schwarze Jura, 97-240. Stuttgart: Schweizerbart.

Quenstedt, F.A. 1885: Die Ammoniten des Schwäbischen Jura. I. Der Schwarze Jura, 241-440. Stuttgart: Schweizerbart.

Schlatter, R. 1977: The biostratigraphy of the Lower Pliensbachian at the type locality (Pliensbach, Württemberg, SW Germany). Stuttgarter Beiträge zur Naturkunde Serie B (Geologie und Paläontologie) 27, 29 pp.

Schlatter, R. 1980: Biostratigraphie und Ammonitenfauna des Unter-Pliensbachium im Typusgebiet (Pliensbach, Holzmaden und Nürtingen; Württemberg, SW-Deutschland). Stuttgarter 
Beiträge zur Naturkunde Serie B (Geologie und Paläontologie) 65, $261 \mathrm{pp}$.

Schlegelmilch, R. 1976: Die Ammoniten des süddeutschen Lias, 212 pp. Stuttgart: Gustav Fischer Verlag.

Simpson, M. 1843: A monograph of the ammonites of the Yorkshire Lias, 60 pp. London: Simpson, Marshall.

Simpson, M. 1855: The fossils of the Yorkshire Lias; described from nature, $149 \mathrm{pp}$. London: Whittaker.

Simpson, M. 1884: The fossils of the Yorkshire Lias; described from nature, 2nd edition, $256 \mathrm{pp}$. Whitby, London: Wheldon.

Sowerby, J. de C. 1826: The mineral conchology of Great Britain 6 (part 88). London: J. de C. Sowerby.

Sowerby, J. de C. 1827: The mineral conchology of Great Britain 6 (part 95). London: J. de C. Sowerby.

Spath, L.F. 1925: Notes on Yorkshire ammonites. The Naturalist 1925 819, 107-112.

Spath, L.F. 1938: A catalogue of the ammonites of the Liassic family Liparoceratidae in the British Museum (Natural History), 191 pp. London: Trustees of the British Museum.

Surlyk, F. \& Noe-Nygaard, N. 1986: Hummocky cross-stratification from the Lower Jurassic Hasle Formation of Bornholm, Denmark. Sedimentary Geology 46, 259-273.

Surlyk, F., Arndorff, L., Hamann, N.E., Hamberg, L., Johannessen, P.N., Koppelhus, E.B., Nielsen, L.H., Noe-Nygaard, N., Pedersen, G.K. \& Petersen, H.I. 1995: High-resolution sequence stratigraphy of a Hettangian-Sinemurian paralic succession, Bornholm, Denmark. Sedimentology 42, 323-354.

Tutcher, J.W. \& Trueman, A.E. 1925: The Liassic rocks of the Radstock district (Somerset). Quarterly Journal of the Geological Society of London 81, 595-666.

Wright, T. 1880: Monograph on the Lias ammonites of the British islands, Part 3, 165-264. London: Palaeontographical Society.

Wright, T. 1882: Monograph on the Lias ammonites of the British islands, Part 5, 329-400. London: Palaeontographical Society.

Manuscript received 17 March 2000; revision accepted 31 May 2000. 
Plates 1-6 


\section{Plate 1}

All figures are at natural size.

Figs 1, 2. Tragophylloceras cf. numismale (Quenstedt).

No. 1976/804[2], from Rønne Lervarefabrik (Ny Østre Lergrav, Rønne).

MGUH 25595.

Figs 3-6. Tragophylloceras numismale (Quenstedt).

No. 1987/94, from Rønne Lervarefabrik (Grube Rønne-Lervareverk), previously figured by Höhne (1933, plate 14, figs 2, 3).

MGUH 25596.

Figs 7-9. Radstockiceras hechingense Schlatter.

No. 1976/805, from Rønne Lervarefabrik (Ny Østre Lergrav, Rønne).

MGUH 25597. 

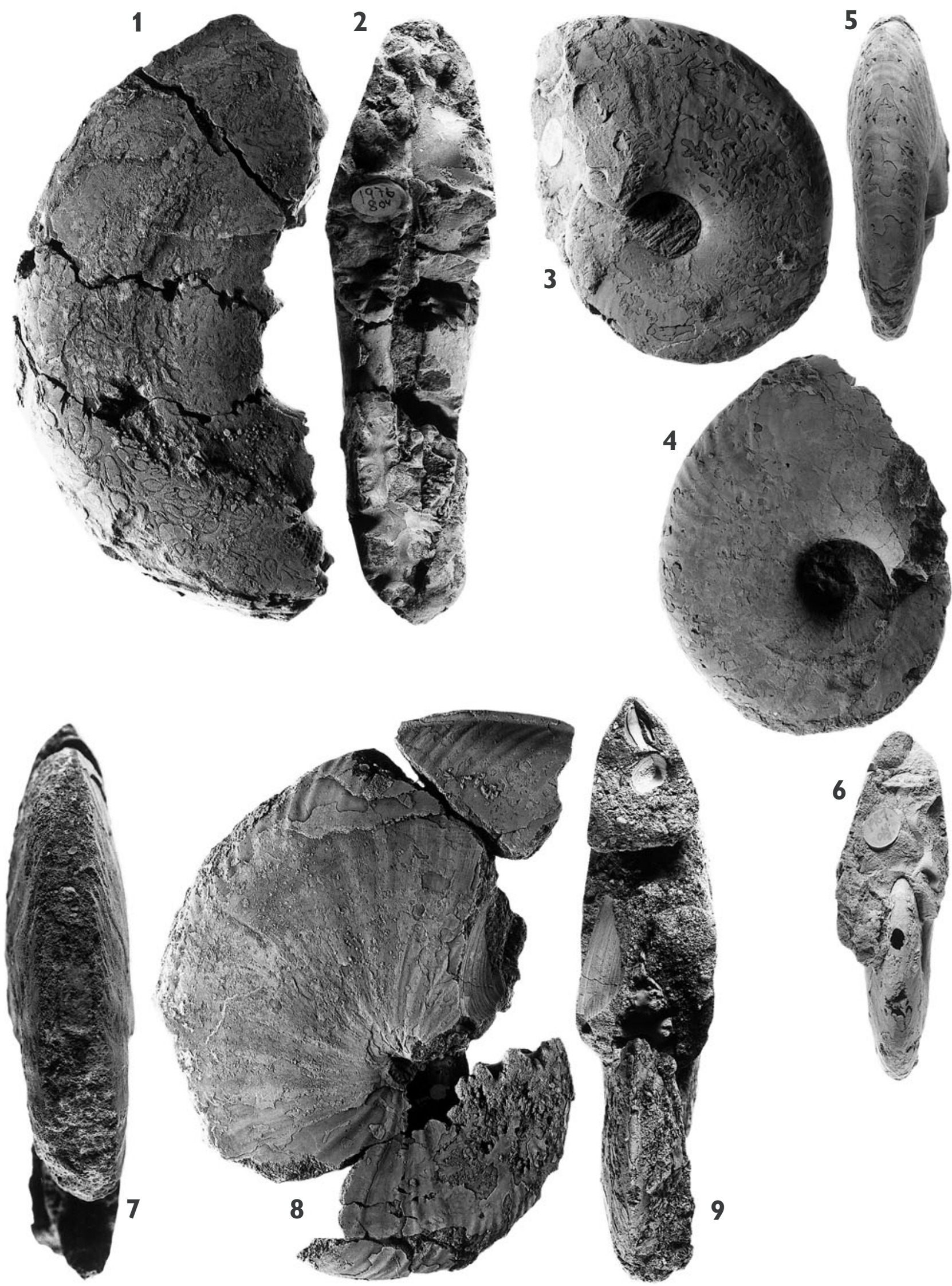


\section{Plate 2}

All figures are at natural size.

Figs 1, 2. Radstockiceras hechingense Schlatter.

No. 1976/804[1], from Rønne Lervarefabrik (Ny Østre Lergrav, Rønne).

MGUH 25598.

Figs 3-5. Apoderoceras aculeatum (Simpson).

No. M 1933/68, from Rønne Lervarefabrik (Ny Østre Lergrav, Rønne).

MGUH 25599-25600.

Figs 6-9. Coeloceras grenouillouxi (d'Orbigny).

No. 1987/92, Rønne Lervarefabrik (new quarry of the Rønne Lervarefabrik). Fig. 9 is specimen no. $1987 / 83$, an impression of the umbilicus of $1987 / 92$.

MGUH 25601-25602.

Figs 10-12. Paramicroderoceras fila (Quenstedt).

No. 1987/93, from Rønne Lervarefabrik (Ny Østre Lergrav, Rønne). MGUH 25603.

Fig. 13. Paramicroderoceras? sp. indet.

No. 1976/806, from Rønne Lervarefabrik (Ny Østre Lergrav, Rønne).

MGUH 25604. 

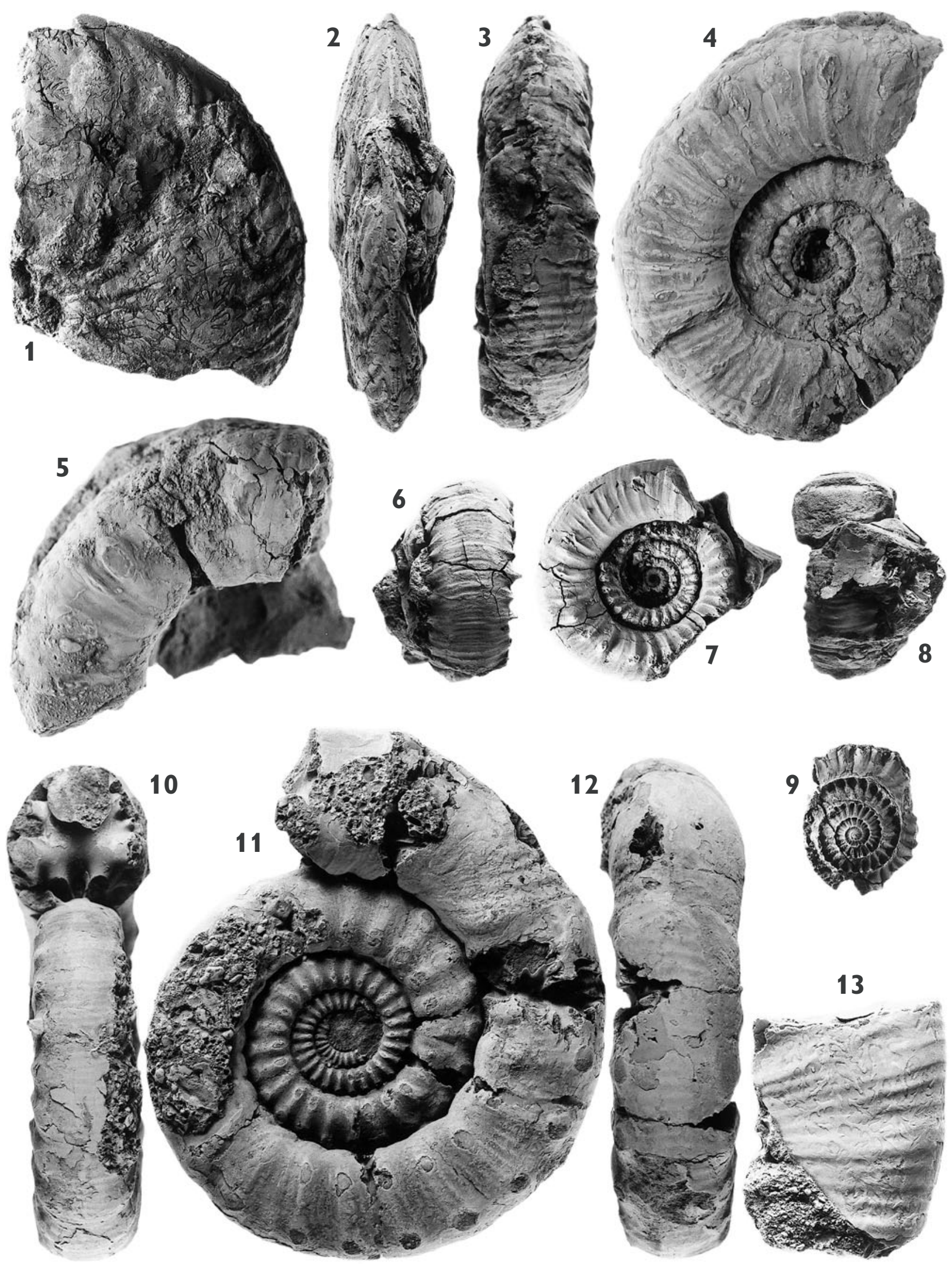


\section{Plate 3}

All figures are at natural size.

Figs 1-6. Platypleuroceras brevispina (J. de C. Sowerby).

1, no. 1976/803; 2, 3, no. 1886/224, both from Sose Odde; 4-6, no. 1976/702, from Rønne Lervarefabrik (Ny Østre Lergrav, Rønne).

MGUH 25605-25607.

Figs 7-9. Platypleuroceras caprarium (Quenstedt), inner whorls.

No. 1987/90, from Rønne Lervarefabrik (Ny Østre Lergrav, Rønne).

MGUH 25608. 


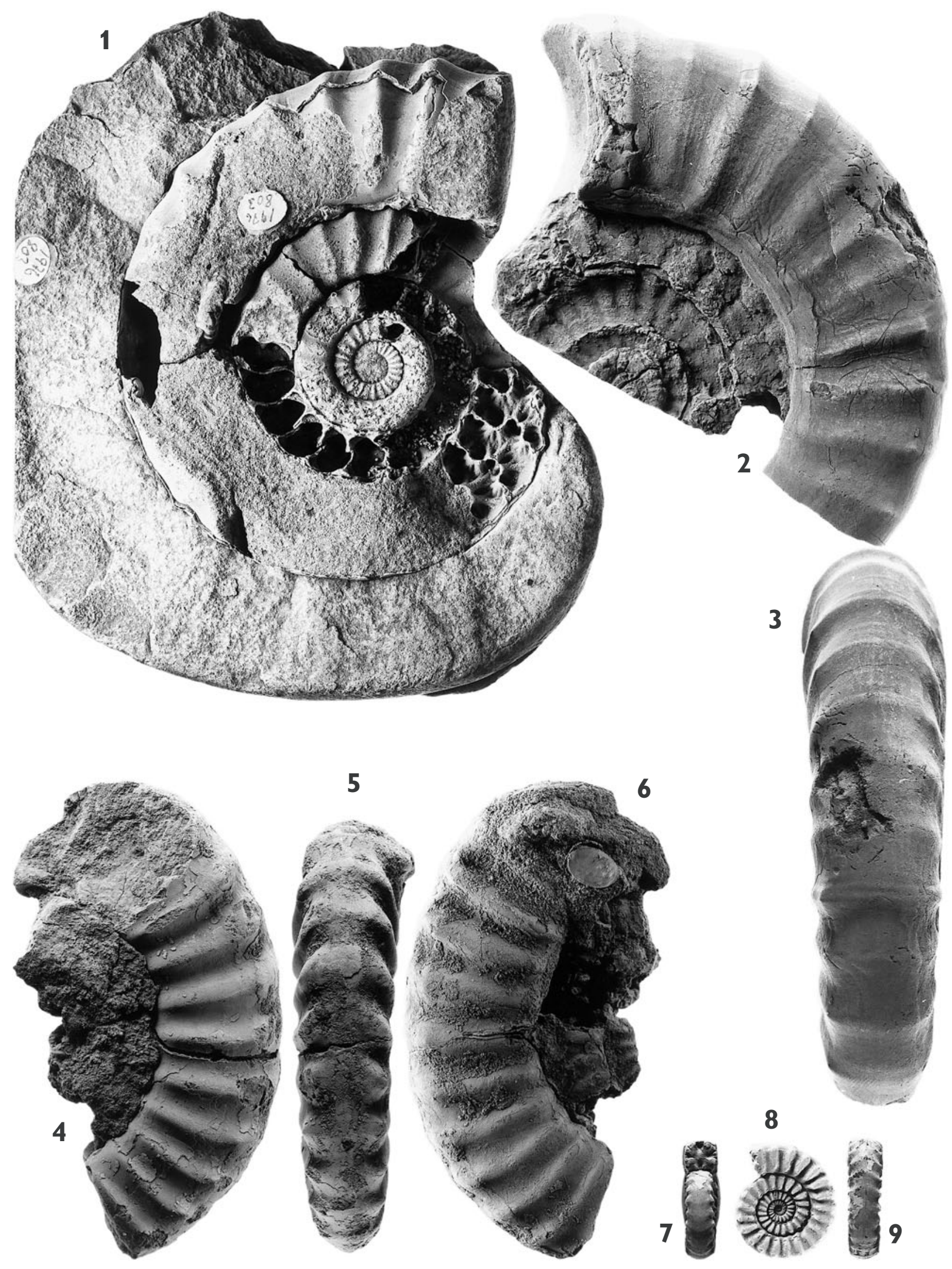




\section{Plate 4}

All figures are at natural size.

Figs 1-6. Platypleuroceras submuticum (Oppel).

1-4, no. 1987/94, 5, 6, no. 1987/808, both from Rønne Lervarefabrik (Rønne Lervarefabriks Ny Grav). MGUH 25609-25610.

Fig. 7. Platypleuroceras sp. indet.

No. 1976/813, found loose on the beach, north of Rønne.

MGUH 25611.

Fig. 8. ?Acanthopleuroceras sp. indet.

No. 1987/84. Bornholm.

MGUH 25612.

Figs 9-13. Phricodoceras taylori (J. de C. Sowerby).

9, 10, no. 1976/810; 11, no. 1976/812; 12, 13, no. 1987/91, from Rønne Lervarefabrik (Ny Østre Lergrav, Rønne).

MGUH 25613-25615. 

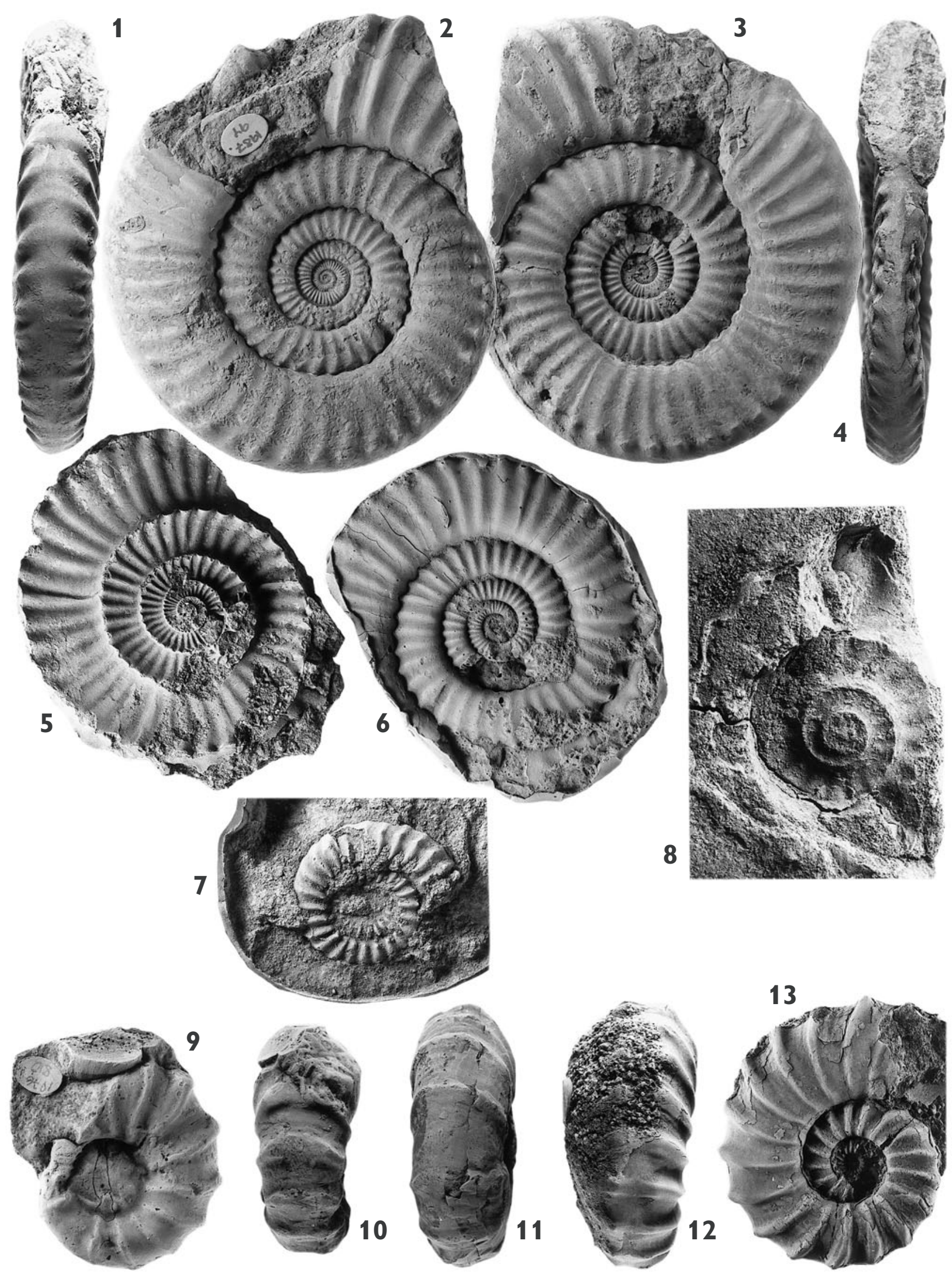


\section{Plate 5}

All figures are at natural size.

Figs 1-21. Platypleuroceras caprarium (Quenstedt).

1, 2, no. 2021, Rønne Lervarefabrik (Rønne Lervarefabriks Nye Grav); 3, 4, no number, Rønne Lervarefabrik (Rønne Lervarefabriks Nye Grav), with aperture preserved; 5, 6, no. 1831 (one of three so numbered), Rønne Lervarefabrik (Rønne Lervarefabriks Nye Grav); 7-9, no number; 10, 11, no. 1987/87, previously figured by Höhne (1933, plate 13, figs. 4, 5); 12-14, no. 1987/88; 15-17, no. 1987/89; 18-21, no. 1987/86 (2 specimens); nos 10-21 from Rønne Lervarefabrik (Ny Østre Lergrav, Rønne).

MGUH 25616-25622. 

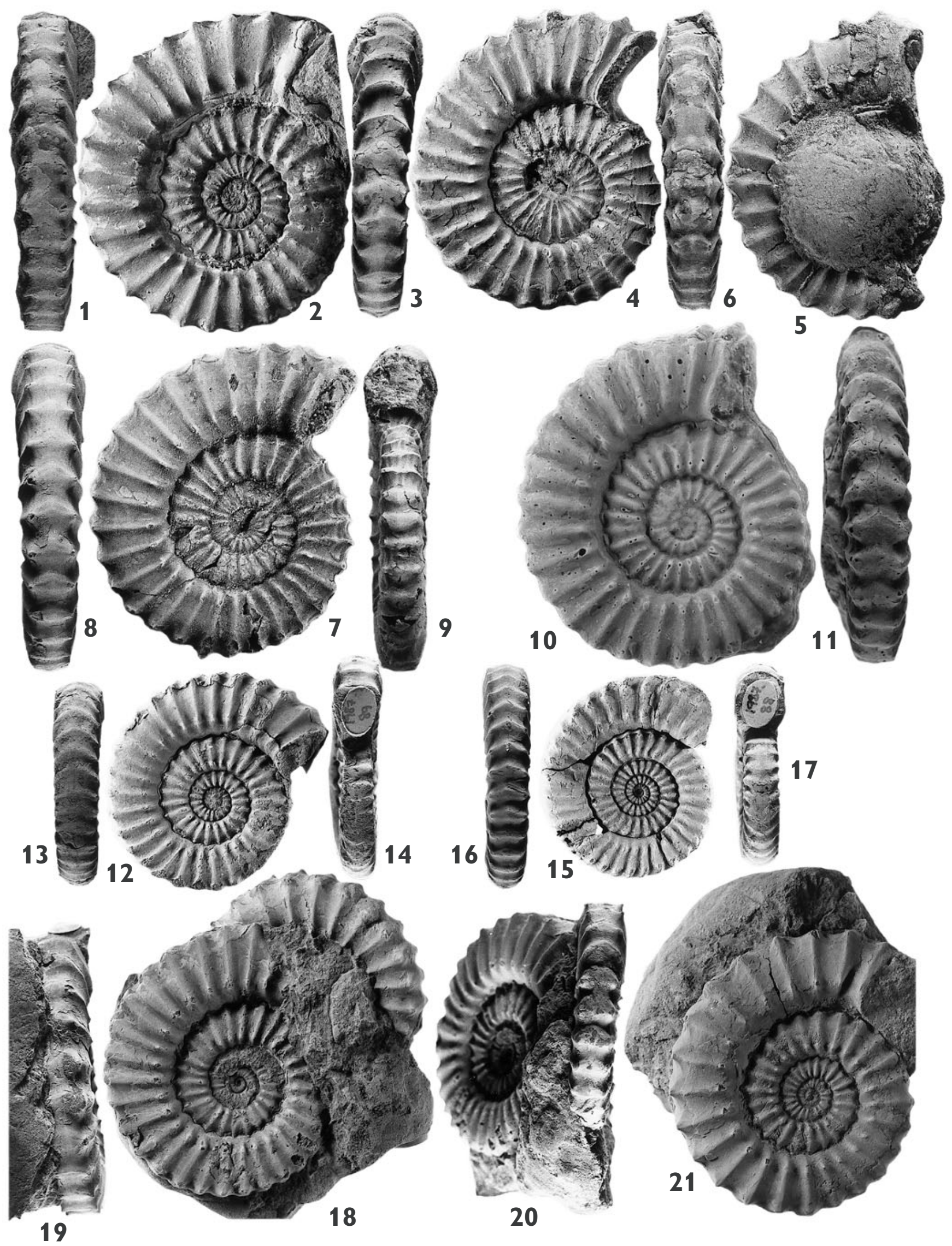


\section{Plate 6}

All figures are at natural size.

Figs 1, 2. Uptonia lata (Quenstedt) (sensu Schlatter).

No. 1987/85, exact locality not known.

MGUH 25623.

Figs 3-5. Phricodoceras taylori (J. de C. Sowerby)

No. 1976/811, from Rønne Lervarefabrik (Ny Østre Lergrav, Rønne). MGUH 25624.

Fig. 6. Platypleuroceras sp. indet.

No. 1976/807, from Rønne Lervarefabrik (Ny Østre Lergrav, Rønne). MGUH 25625.

Fig. 7. Uptonia sp. indet.

No. 1976/801, from Rønne Lervarefabrik (Ny Østre Lergrav, Rønne). MGUH 25626.

Figs 8-10. Platypleuroceras submuticum (Oppel).

No. 1975/1491, from Rønne Lervarefabrik (Rønne Lervarefabriks Ny Grav).

MGUH 25627. 


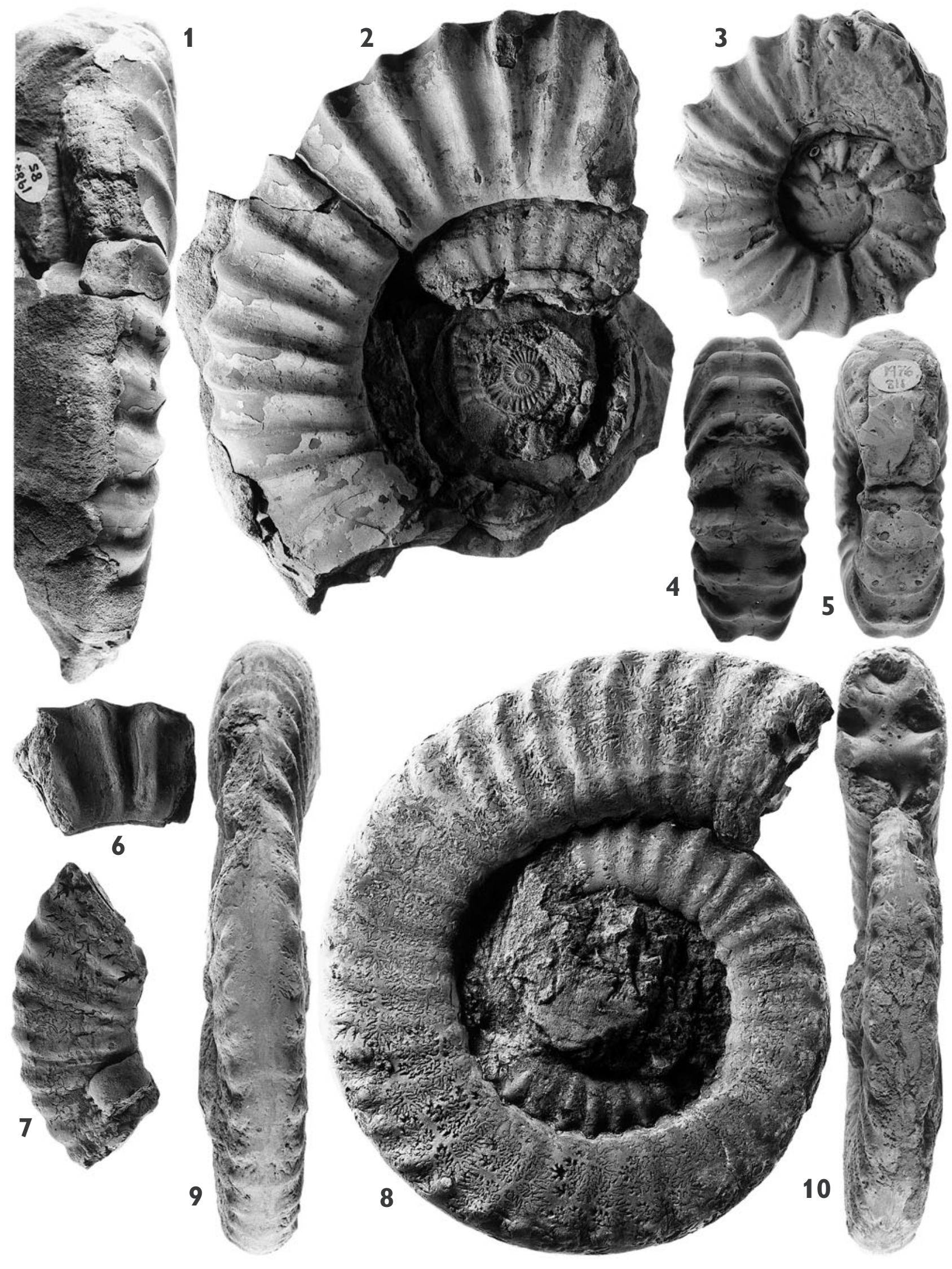


